\title{
Banking Deregulations and Unemployment in South Asia
}

\author{
Muhammad Zakaria \\ COMSATS Institute of Information Technology, Islamabad, Pakistan \\ Rida Risalat \\ COMSATS Institute of Information Technology, Islamabad, Pakistan \\ Bashir A. Fida \\ Modern College of Business and Science, Muscat, Oman
}

\begin{abstract}
The paper empirically examines the effects of banking deregulations on overall and youth unemployment rates in South Asian countries using panel data for the period 1991 to 2005. The results show that banking deregulations have decreased the youth unemployment rate in the region. The results also reveal that high consumption level, per capita income and bank credit have reduced the unemployment rate, while bank crisis and high wage rate have increased the unemployment rate in the region. The results suggest that banking liberalization may help to reduce unemployment particularly youth unemployment in South Asian countries.
\end{abstract}

JEL Classifications: C23, E24, G21

Keywords: Banking Deregulations, Unemployment, South Asia

\footnotetext{
* Corresponding Author: Muhammad Zakaria; Department of Management Sciences, COMSATS Institute of Information Technology, Park Road, Chak Shahzad, Islamabad, Pakistan; Tel: +92 3335998865, E-mail: mzakaria80@hotmail.com. Co-Author: Rida Risalat; Department of Management Sciences, COMSATS Institute of Information Technology, Park Road, Chak Shahzad, Islamabad, Pakistan; Tel: + 92 3335804670, E-mail: ridascn@gmail.com.

Bashir A. Fida; Modern College of Business and Science, P.O. Box 100, Post code 133, Alkuwair, Muscat, Oman; Tel: +96 892310572, E-mail: bashir@mcbs.edu.om.
} 


\section{Introduction}

The financial sector plays an important role in the economic development of a country. Countries which have deregulated their banking sectors have enjoyed higher economic growth rates than countries which have regulated financial systems. In addition, banking deregulations also have favorable impacts on other sectors of the economy, like income inequality, unemployment, entrepreneurship, and investment. Having a regulated banking system is considered to be an important factor in increasing equilibrium unemployment by imposing credit constraints and restricting the firm entry (Acemoglu 2001, Wasmer and Weil 2004). In turn, banking deregulation helps to increase the competition and efficiency ${ }^{1}$ within the banking sector, which increases the performance of the banking sector. A highly competitive and efficient banking system provides loans to entrepreneurs and business firms at low cost, which increases investment by easing capital availability. This increase in investment increases the demand for labor, which in turn decreases the unemployment rate (Dromel et al. 2010, Strahan 2003). Banking deregulation reduces entry barriers for foreign banks, so consumers can have more choices for products and services at a low cost (Krol and Svorny 1996). These foreign banks further improve the supply of credit in the capital market, which helps to reduce unemployment by increasing investment (Saeed 2009). Banking deregulation also reduces unemployment by boosting income in the lower parts of the income distribution (Beck et al. 2010). However, opponents argue that easing financing constraints may allow firms to optimally substitute capital for labor (Garmaise 2008) by investing in more capital-intensive technologies, which increases unemployment. Thus, theoretically the effect of banking deregulation on unemployment is equivocal.

Until now, only a few studies have empirically analyzed the effect of banking deregulations on labor market performance and most of them have been conducted in the United States. ${ }^{2}$ These empirical studies have shown that banking reforms have decreased the unemployment rate. Recently, Boustanifar (2014) examines the impact of credit market development on employment in the US using banking reform data between the 1970s and 1990s. The study reveals that the banking reforms have had a significant effect on employment growth in the US. The study suggests that labor has

\footnotetext{
Here, efficiency means provision of financial services, especially lending services, in timely manner at relatively low cost.

See Butkiewicz and Latham (1991), Krol and Svorny (1996), Beck et al. (2010), and Demyanyk (2008).
} 
a fixed cost that needs to be financed. In the UK, Blanchflower and Shadforth (2007) find that financial liberalization increased self-employment in the 1980s. However, Baddeley (2008) stipulates that liberalization decreased employment in the UK in the period 1979 to 2005. Some panel studies have also been conducted. Acemoglu (2001), using sectoral employment data in the Organization for Economic Co-operation and Development (OECD) countries, documents that credit market imperfections may not be the major source of increase in European unemployment, however, it has limited European employment growth. Dormel et al. (2010), using data on 20 OECD countries for the period 1982 to 2003, show that credit constraints not only increase steady-state unemployment, but also slow down transitional dynamics.

Feldmann (2006), using data from 74 industrial, developing, and transition countries for the period 2000 to 2003, empirically analyzes the impacts of credit market regulations on the performance of the labor market. The study reveals that anticompetitive credit market regulations have an adverse impact on the labor market as it increases unemployment, particularly among young people. In another study, Feldmann (2012) using data on 53 countries suggests that banking liberalization has substantially decreased unemployment, especially youth unemployment. The study suggests that lowering of barriers to the entry of foreign banks, new domestic banks, and non-bank financial intermediaries, and the reduction in state ownership, have the strongest effects. Pagano and Pica (2012) using international industry-level data for 1970 to 2003, find that financial development is associated with greater employment growth. Since no study has been conducted in South Asia so far, this study attempts to fill this gap by empirically examining the effect of banking deregulations on unemployment, specifically youth unemployment, in South Asian countries.

South Asian countries bear many similar characteristics which justify combining these countries for analysis. These countries are at a similar stage of economic development. They have also initiated many similar reforms like fiscal decentralization, promotion of the private sector, growth of stock markets, development of modern banking system, and opening their borders for foreign trade and investment. Further, South Asian countries were initially closed economies but gradually shifted from import substitution policies to export-led growth. These neighboring countries are promoting trade and investment with each other and are moving towards a regional trade agreement. Moreover, South Asian countries have a large share of world population and are located in the same geographical region. Thus, it is interesting to examine how banking deregulation has affected unemployment in this part of the world. 
The rest of the paper is organized as follows. Section II elaborates financial reforms in South Asia. Section III briefly discusses the unemployment situation in South Asia. Section IV explains the theoretical framework. Section V provides the estimated results along with their interpretations. The final section concludes the paper.

\section{Financial Reforms in South Asia}

\section{A. Bangladesh}

Reforms in Bangladesh's financial services industry were initiated in 1987. In 1992, the Financial Sector Reform Program (FSRP) was introduced which helped in the implementation of reforms which brought many structural changes to the banking sector. The objective of the financial reforms was to improve competition among banks and to increase the efficiency of the financial sector. It focused on deregulating interest rates, improving loan classification standards, reducing direct control of Bangladesh Central Bank's on financial transactions and loan recovery measures, strengthening the operations of the banking system by improving the legal environment, computerizing banks, and improving the capital adequacy of banks. Both deposit and lending rates were deregulated which empowered banks to set different interest rates for individuals depending on the risks involved in different transactions. These reforms opened the financial sector for private banks.

\section{B. India}

India introduced financial reforms in two different phases. The first phase was suggested by the Narsimham Committee 1991, also known as the Financial System Committee 1991, which includes measures for strengthening the financial system. In the second phase the government appointed another Narsimham Committee in 1998, better known as the Banking Sector Committee 1998, to review banking reform progress and design a program for further strengthening of the financial system of India. The committee focused on various areas such as capital adequacy, bank mergers, and bank 
legislation. The phases were designed to facilitate each other's goals and to achieve a higher level of competitiveness and stability in the banking system. The financial reforms included interest rate liberalization, reserve requirement reduction, reducing entry barriers and ownership restrictions, credit policies, and prudential banking supervision. Banking supervision requirements were tightened under the reforms which included introduction of a capital adequacy requirement, asset classification, and provisioning norms. The bank equity, asset quality and profitability of the banks improved after banking sector reforms.

\section{Pakistan}

The banking sector reform programs in Pakistan were initiated in 1988 and were completed in three different phases during 1988 1996, 1997 2001, and 2002 2004. These reforms were started under the macroeconomic and financial sector restructuring guidance of the International Monetary Fund (IMF). The objectives of these reforms were the privatization of commercial banks, removal of entry restrictions of private banks, introduction of subsidized credit schemes, elimination of the credit ceiling system and caps on deposit and lending rates, market based credit distribution, and lowering of legal requirement for banks. In order to enable the government to sell capital share of the nationalized banks, Banks (Nationalization) Act of 1974 was amended in 1990, which allowed the private sector to operate in the banking industry. As a result of successful attainment of these reforms, financial discipline and stability have been established in Pakistan. Reforms have not only developed the macro-financial system, but have also resulted in improving the performance of individual banks.

\section{Sri Lanka}

Sri Lanka is the first country in South Asia to implement both financial and trade reforms, which began in late 1970s. Initial reforms during 1977 to 1988 focused mainly on the establishment of a sound financial infrastructure. Afterward, the second phase of the reform program started in 1989 and aimed at stabilizing and further liberalizing the economy in order to support non-public enterprises. The third phase of reform was initiated in 1994 to rationalize the economic reform process with public scrutiny. The 
banking deregulation program in Sri Lanka aimed at the introduction of new financial instruments, improving the interest rate policy, reform of the credit and exchange rate control system, relaxation in allocation of credit, and privatization of financial institutions. The size of the financial sector expanded significantly after the financial reforms and the banking industry has become more competitive in Sri Lanka.

\section{Unemployment in South Asia}

South Asia is a highly populated region as more than one fifth of the world's population is living in this region. Due to high population, unemployment is high in this region. Although stable economic growth, trade liberalization, and financial reforms have helped to reduce the unemployment level in the region, South Asian countries are still facing the problem of high unemployment and are unable to create sufficient amount of new job opportunities, especially for the young labor force. Figures 1 and 2 describe total and youth unemployment trends in South Asian countries. It is evident from the figures that both the overall and youth unemployment rates are high. The youth unemployment rate is higher than the overall unemployment rate because youth population lack the necessary skills, experiences, and financial resources to find new jobs. The unemployment rate is relatively higher in Sri Lanka compared to other countries in the region because of its civil war during 1983 2009. In Pakistan, unemployment rate also increased in the early 2000 s in the wake of the 9/11 event. However, it decreased in late 2000s as Pakistan received a high influx of workers' remittances and foreign aid especially from the US for working as a frontline state against terrorism. This helped to stabilize the economy and to maintain a high economic growth rate in the mid 2000s. High foreign investment in Pakistan also helped to reduce unemployment in the 2000s.

One third of the population in South Asia is living below poverty line and on average, about half of the population in the four bigger countries is illiterate. Due to the low literacy rate in the region, uneducated people are unable to meet the requirements of high-tech jobs so the unemployment of the unskilled or low skilled labor force is increasing in these countries. Lack of investment and low productivity is also creating unemployment. Further, due to the mechanization of the agriculture sector, unemployment among the agriculture labor force has increased in these countries. 


\section{Figure 1. Overall unemployment rate}

(Measurement unit: Percentage)

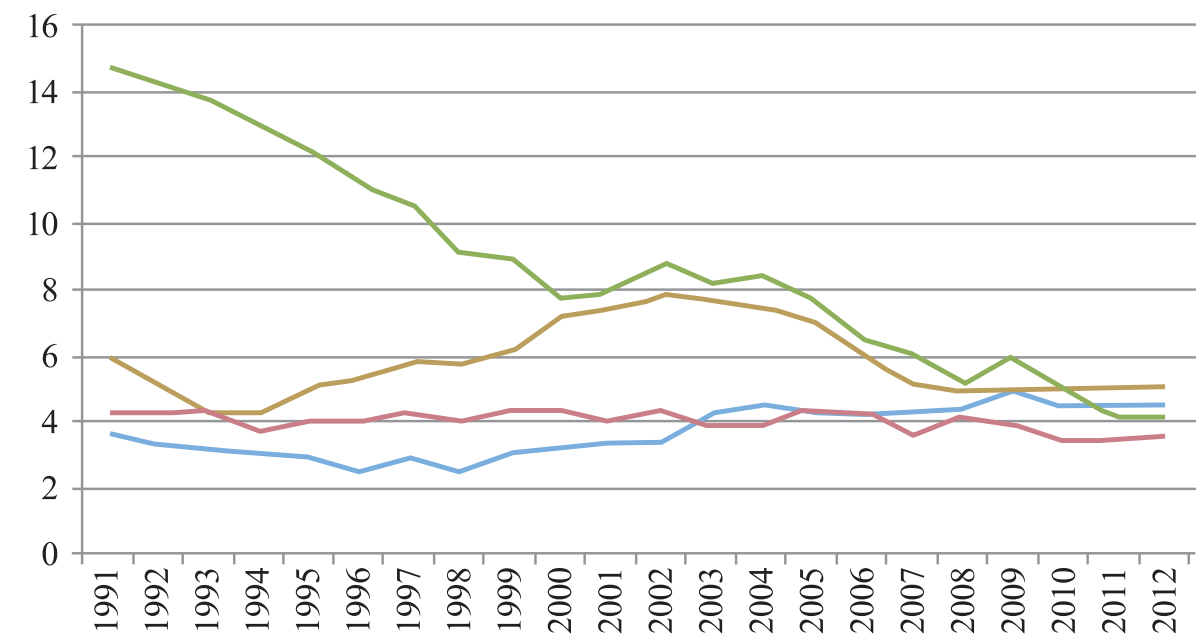

- Bangladesh India - Pakistan - Sri Lanka

Figure 2. Youth unemployment rate

(Measurement unit: Percentage)

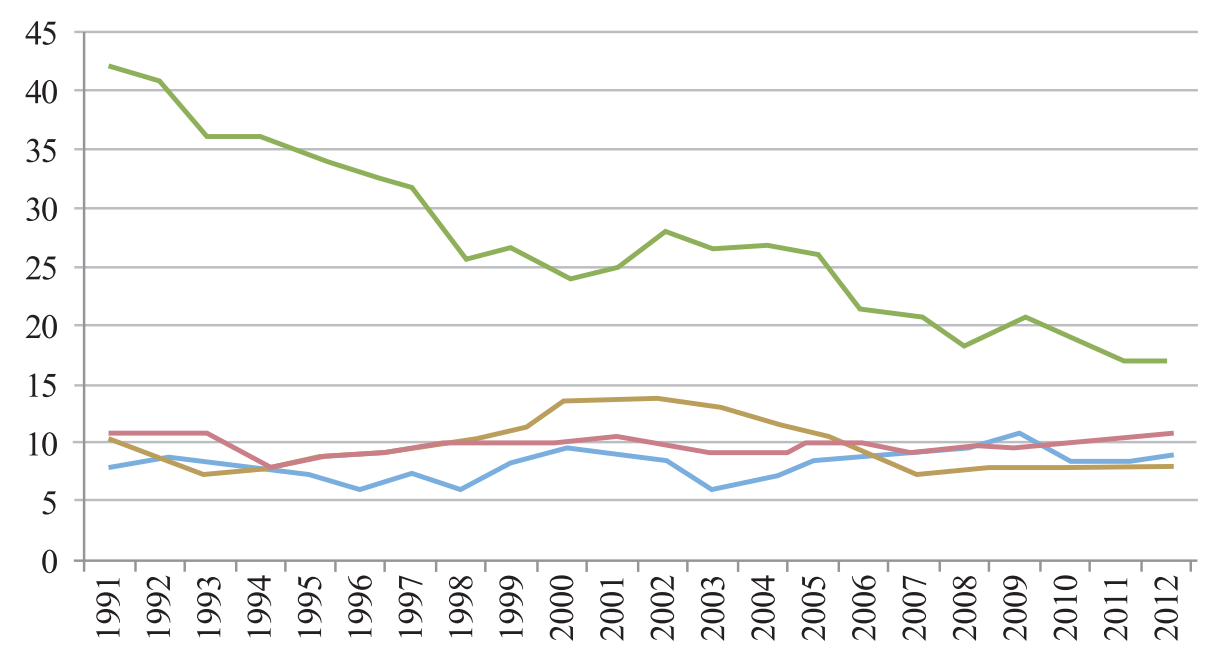

- Bangladesh India - Pakistan - Sri Lanka 


\section{Analytical Framework}

The study examines the effect of banking deregulation on overall and youth unemployment rates. Theoretical literature has highlighted various variables which affect unemployment rates. These variables are categorized into banking deregulation and control variables. Banking deregulation variables included are interest rate control, credit control, competition restriction, state ownership, and banking supervision. Control variables are systematic banking crisis, consumption, agricultural growth, income, bank credit, and wage rate. Figure 3 provides a schematic representation of the theoretical framework.

\section{Figure 3. Theoretical framework}

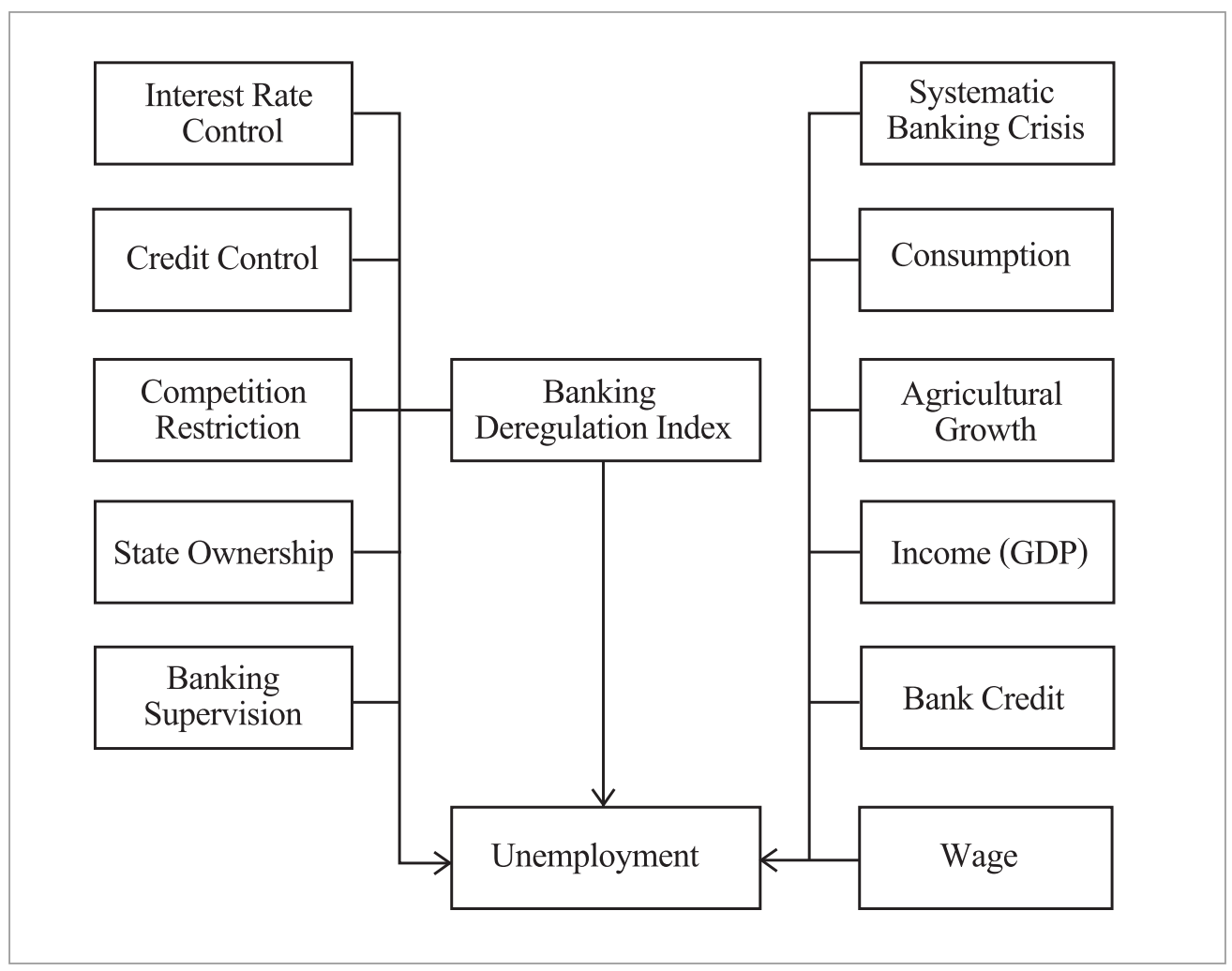

In econometric form, the theoretical models for overall and youth unemployment rates are explained by Equations (1) and (2), respectively. 


$$
\begin{aligned}
U E_{i t}=\alpha_{0}+ & \alpha_{1} B D_{i t}+\alpha_{2} S B C_{i t}+\alpha_{3} G_{i t} \\
& +\alpha_{4} G D P_{i t}+\alpha_{5} A G_{i t}+\alpha_{6} B C_{i t}+\alpha_{7} W_{i t}+\alpha_{8} U E_{i t-1}+\mu_{i t}
\end{aligned}
$$

Where $U E$ is total unemployment rate; $U E Y$ is youth unemployment rate; $B D$ is banking deregulation variables, i.e., interest rate control, credit control, competition restriction, state ownership, and banking supervision; $S B C$ is systematic banking crisis; $G$ is private and government consumption expenditures; GDP is per capita Gross Domestic Product (GDP); $A G$ is agricultural growth rate; $B C$ is bank credit to private sector, and $W$ is wage rate. Overall, six specifications will be estimated for each equation. The first specification will be estimated to examine the combined effect of banking deregulation measures on unemployment by including a banking deregulation index while the remaining five specifications will be estimated to capture the separate impact of each of the five dimensions of banking deregulations on unemployment. Theoretical justification of these variables is explained in Table 1.

\section{Table 1. Theoretical justification of the variables}

\begin{tabular}{|l|l|}
\hline $\begin{array}{l}\text { Interest } \\
\text { rate control }\end{array}$ & $\begin{array}{l}\text { It includes restrictions both on lending and deposit rates. High interest } \\
\text { rate controls make the capital market ineffective, which adversely } \\
\text { affects the economy by discouraging investment. High credit controls } \\
\text { restrict credit availability, which decreases investment and increases } \\
\text { unemployment (Acemoglu 2001). }\end{array}$ \\
\hline $\begin{array}{l}\text { Credit } \\
\text { control }\end{array}$ & $\begin{array}{l}\text { Credit controls affect credit ceilings, credit floors, and reserve } \\
\text { requirements. They are used to control the demand and supply of money. } \\
\text { Credit control results in credit market imperfections, which increase } \\
\text { unemployment by restricting access to money (Dormel et al. 2010). }\end{array}$ \\
\hline $\begin{array}{l}\text { Competition } \\
\text { restriction }\end{array}$ & $\begin{array}{l}\text { It measures restrictions for the entry of foreign banks. These restrictions } \\
\text { may be due to geographical area for operation, licensing requirements, } \\
\text { or by putting limits on bank activities. It decreases competition among } \\
\text { banks by restricting the entry of new banks, which is likely to increase } \\
\text { inefficiency in the banking system (Claessens and Laeven 2004). It may } \\
\text { increase the unemployment rate in the economy. }\end{array}$ \\
\hline
\end{tabular}




\begin{tabular}{|c|c|}
\hline $\begin{array}{l}\text { State } \\
\text { ownership }\end{array}$ & $\begin{array}{l}\text { It means how much banking assets are controlled by the state bank. } \\
\text { Generally, state-owned banks are responsible for poor performance of } \\
\text { the banking sector (Caprio and Martinez-Peria 2000). Privatization of } \\
\text { the banking sector increases the competitive environment among banks, } \\
\text { which increases their efficiency. An efficient banking system provides } \\
\text { financial services at a lower cost, which decreases the unemployment } \\
\text { rate. }\end{array}$ \\
\hline $\begin{array}{l}\text { Banking } \\
\text { supervision }\end{array}$ & $\begin{array}{l}\text { It measures the ability of the banks to make their own decisions and } \\
\text { their capacity to manage default risk. Poor transparency within the } \\
\text { banking sector leads to poor performance of the financial sector (Mehrez } \\
\text { and Kaufmann 2000), which increases unemployment by providing low } \\
\text { quality services. }\end{array}$ \\
\hline $\begin{array}{l}\text { Systen } \\
\text { banki }\end{array}$ & $\begin{array}{l}\text { A systematic banking crisis usually occurs when the financial system } \\
\text { is not stable. It is found that banking crises increases unemployment } \\
\text { via high lending rates, which reduce investment and economic growth } \\
\text { (Bernal-Verdugo et al. 2012). This variable is included in the model to } \\
\text { analyze whether banking deregulations reduce unemployment when } \\
\text { such crises are controlled. }\end{array}$ \\
\hline Con & $\begin{array}{l}\text { It is an important component of aggregate demand. When consumption } \\
\text { spending increases demand for goods will increase. To meet this high } \\
\text { demand, production will increase which will generate employment. } \\
\text { Thus, high consumption expenditures will decrease the unemployment } \\
\text { rate (Gruber 1997). }\end{array}$ \\
\hline $\begin{array}{l}\text { Agricultural } \\
\text { growth }\end{array}$ & $\begin{array}{l}\text { Developing countries mainly depend on agricultural growth for } \\
\text { economic development. Increase in the productivity of the agricultural } \\
\text { sector helps in the creation of employment in these countries. Thus, } \\
\text { growth in the agriculture sector decreases the unemployment rate in less } \\
\text { developed countries. }\end{array}$ \\
\hline Inco & $\begin{array}{l}\text { According to Okun's law economic growth and unemployment } \\
\text { are closely related with each other. High economic growth will } \\
\text { create employment opportunities and in the long run, decrease the } \\
\text { unemployment rate. }\end{array}$ \\
\hline Banl & $\begin{array}{l}\text { Bank credit is considered an important indicator for the development } \\
\text { of the banking sector. Bank credit to the private sector helps to increase } \\
\text { employment by increasing investment and economic growth. This } \\
\text { variable is included in the model to ensure that banking regulation } \\
\text { variables do not proxy for this variable. }\end{array}$ \\
\hline Wage rate & $\begin{array}{l}\text { Labor market theory postulates that when the wage rate increases } \\
\text { the supply of labor increases and the demand for labor decreases. It } \\
\text { increases the unemployment rate in the economy. Further, when the } \\
\text { wage rate increases beyond a certain level, it will increase the wealth of } \\
\text { the workers so workers will prefer leisure over work. This wealth effect } \\
\text { will also increase the unemployment level. }\end{array}$ \\
\hline
\end{tabular}




\section{Data and Models}

\section{A. Data}

Annual data is collected for four South Asian countries consisting of Bangladesh, India, Pakistan, and Sri Lanka ${ }^{3}$ for the period 1991 to $2005 .{ }^{4}$ Overall unemployment rate is defined as total unemployed labor force percentage of total labor force. Youth unemployment rate is unemployed labor force in the age group of 15 24 years and is taken as a percentage of labor force of that age group. Banking deregulation index is an unweighted average of five sub-indices, i.e., interest rate control, credit control, competition restriction, state ownership, and banking supervision. High value of this index represents more banking deregulation or financial liberalization. Systematic banking crisis is a dummy variable which takes the value of 1 for the year in which a crisis took place and zero otherwise. Consumption variable is the sum of private and government expenditures and is taken as a percentage of GDP. Bank credit is domestic credit to the private sector as a percentage of GDP. This ratio also measures financial development in the country. Data for dependent variables is collected from Key Indicators of the Labour Market (KILM) and International Labour Office (ILO). Wage data is also taken from ILO. Data for control variables data is taken from World Development Indicators. Data for banking deregulation variables is taken from Abiad et al. (2008).

Table 2 provides descriptive statistics of the variables which are used in this study. It shows that compared to the overall employment rate, the youth unemployment rate is high where the mean value is $14.78 \%$ and has a range of 6.20 to $41.70 \%$. It is also observed that the youth unemployment rate has more fluctuations compared to the overall unemployment rate as the value of the standard deviation is high for the youth unemployment rate, 9.88, compared to the total unemployment rate, 3.11. In all variables, income per capita has the highest fluctuations as the high value of its standard deviation indicates, 250.18. The values of the standard deviations will help us in the interpretation of the results.

\footnotetext{
${ }^{3}$ Due to data unavailability, Afghanistan, Bhutan, the Maldives, and Nepal are not included in the analysis.

${ }^{4}$ Except for Sri Lanka, all other South Asian countries initiated financial reforms in the early 1990s, so the start date is 1991. Data for banking regulation measures is not available after 2005 so the end date is 2005 .
} 
Table 2. Descriptive statistics

\begin{tabular}{|l|c|c|c|c|c|}
\hline Variables & Mean & Median & Maximum & Minimum & $\begin{array}{c}\text { Standard } \\
\text { deviation }\end{array}$ \\
\hline Overall unemployment rate (\%) & 6.01 & 4.40 & 14.70 & 2.50 & 3.11 \\
\hline Youth unemployment rate (\%) & 14.78 & 10.05 & 41.70 & 6.20 & 9.88 \\
\hline Banking deregulation index & 1.26 & 1.20 & 2.40 & 0.20 & 0.50 \\
\hline Interest Rate Control & 1.95 & 2 & 3 & 0 & 0.91 \\
\hline Credit control & 1.83 & 2 & 3 & 0 & 0.84 \\
\hline Competition restriction & 1.18 & 1 & 3 & 0 & 0.85 \\
\hline State ownership & 0.35 & 0 & 2 & 0 & 0.55 \\
\hline Banking supervision & 0.97 & 1 & 2 & 0 & 0.80 \\
\hline Systematic banking crisis & 0.15 & 0 & 1 & 0 & 0.36 \\
\hline Consumption (\% of GDP) & 82.01 & 83.12 & 88.67 & 68.47 & 4.36 \\
\hline Agricultural growth (\%) & 2.76 & 2.82 & 11.72 & -6.60 & 3.64 \\
\hline Income, per capita (US \$) & 609.01 & 578.59 & 1242.40 & 272.17 & 250.18 \\
\hline Bank credit (\% of GDP) & 30.56 & 28.38 & 58.36 & 8.82 & 12.87 \\
\hline Wage index & 74.92 & 76.48 & 153.37 & 29.87 & 25.63 \\
\hline
\end{tabular}

\section{B. Estimation of the models}

We cannot estimate our model using the least square method as the potential endogeneity of the variables can render the least square estimators to be biased and inconsistent. Endogeneity is likely to arise mainly due to reverse causality between some explanatory variables and due to the inclusion of a lagged dependent variable in the estimation. In other words, endogeneity problem arises because some variables are endogenous and are therefore likely to be correlated with the error term. To obtain consistent parameter estimates in panel data, we have to apply the Two Stage Least Square (2SLS) estimation technique (Wooldridge 2002). This method is based on the principle of instrumental variables. Lagged values of the variables are used as instruments under the assumption that, although there may be correlation between explanatory 
variables and the error term, which does not exist between the lagged variables and the error term. ${ }^{5}$ To control for the possibility of cross-sectional heteroscedasticity, which affects the efficiency of the estimators and the validity of hypothesis testing and inference, the models are estimated using the Generalized Least Squares (GLS) method with cross-sectional weights and White cross-section standard errors and covariance. The correction for heteroscedasticity improves the statistical significance of the regressors.

The models (1) and (2) are estimated using the fixed effect technique. To select between the Fixed Effect Model (FEM) and the Random Effect Model (REM), the Hausman (1978) test is used. REM is preferred under the null hypothesis due to higher efficiency, while under the alternative hypothesis FEM is at least consistent and thus preferred. However, we cannot apply the Hausman test because we cannot estimate our model using REM as the number of parameters to be estimated is greater than cross section units. Hence, we have to estimate our model using the fixed effect technique.

The models are estimated with alternative specifications ${ }^{6}$ and results are reported in Tables 3 and 4 for total unemployment and youth unemployment, respectively. The first column report the results using the banking deregulation index variable along with control variables. The rest report the results using the banking deregulation dimensions one by one. High values of coefficient of determination $\left(R^{2}\right)$ indicate that independent variables explain more than $95 \%$ of the variation in the total unemployment rate and more than $94 \%$ of the variation in the youth unemployment rate. It indicates that estimated models have high explanatory power. The values of Durbin $|h|$ are less than $|1.96|$ which indicate the absence of autocorrelation problem in the models. The explanatory variables of the model are jointly significant as high values of $F$-statistics indicate, which also suggest that our models fit the data well. To test the validity of the instruments, $J$-statistic, which is also known as the Sargan statistic, for over-identifying restrictions is used. Under the null hypothesis that the over-identifying restrictions are valid, the Sargan statistic is distributed as a $x(p-k)$, where $k$ is the number of estimated coefficients and $p$ is the instrument rank. High $p$-values of $J$-statistics in the table indicate that the instruments are valid. Finally, high $p$-values of the Jarque-Bera (JB) test show that the data is normally distributed.

\footnotetext{
${ }^{5}$ Rather than using changes in lagged $x_{i t}$ as instruments, we can use lagged levels of $x_{i r}$. For example, choosing $\left(x_{i, t-1}, x_{i, t-2}\right)$ as instruments at time $t$ is no less efficient than the procedure that uses $\left(\Delta x_{i,-1}\right)$, as the latter is a linear combination of the former (Wooldridge 2002).

${ }^{6}$ Table in the Appendix provides correlation between banking deregulation measures. All these measures are significantly correlated with each other. So we cannot estimate our models by including all these measures together as it will create a multicollinearity problem. Therefore, we have estimated our models with alternative specifications.
} 
The estimated coefficient of the banking deregulation index is negatively related with both the overall and youth unemployment rates but it is significant only for the youth unemployment rate. This indicates that one standard deviation increase in banking deregulation (0.50) is associated with a fall in the youth unemployment rate of $0.1435 \%$. This result indicates that more limp, flexible, and competitive regulations in banking sector will decrease the youth unemployment rate in South Asian countries. This result is consistent with the evidence found in the literature that financial liberalization helps to improve the labor market performance.

Credit control, state ownership, and banking supervision have a negative effect while interest rate control and competition restrictions have a positive effect on total unemployment. However, all these variables are statistically insignificant. All components of the banking deregulation index have statistically significant negative effects on the youth unemployment rate. The negative coefficient on interest rate control indicates that the liberalization of lending and deposit rates can decrease youth unemployment. The credit control variable indicates that if governments decrease floors and ceilings on credit and lower the reserve requirement then youth unemployment will decrease in the region. The negative coefficient on competition restriction indicates that reduction in the restrictions on the entry of foreign banks like licensing requirements, credit allocation controls, geographical limitations for the banks to operate can improve banking efficiency via high competition (Claessens and Laeven 2004). It also helps to reduce the youth unemployment rate in the region. Interestingly, state ownership is also found to have a negative effect on the youth unemployment rate. This is in contrast with the theory that privatization in the banking sector increases efficiency and competitiveness within the banking sector, which increases easy access to credit and causes unemployment to decrease. Finally, the significant coefficient of banking supervision shows that if the banking sector of South Asian countries adopts capital adequacy ratios and effective on-site and off-site examinations of the banks, this can be a good contributor to the reduction of youth unemployment. Thus, the estimated result shows that deregulation of the banking sector in South Asian countries has reduced the youth unemployment rate. 
Table 3. Total unemployment rate

(Estimated results)

\begin{tabular}{|c|c|c|c|c|c|c|}
\hline & (1) & (2) & (3) & (4) & (5) & (6) \\
\hline Constant & $\begin{array}{c}3.872 \\
(0.458)\end{array}$ & $\begin{array}{c}7.105 \\
(1.902)^{* *}\end{array}$ & $\begin{array}{c}3.359 \\
(0.664)\end{array}$ & $\begin{array}{c}5.854 \\
(1.730)^{* *}\end{array}$ & $\begin{array}{l}3.137 \\
0.713\end{array}$ & $\begin{array}{l}2.762 \\
0.458\end{array}$ \\
\hline Banking deregulation index & $\begin{array}{c}-0.031 \\
(-0.164)\end{array}$ & & & & & \\
\hline Interest rate control & & $\begin{array}{c}0.040 \\
(0.736)\end{array}$ & & & & \\
\hline Credit control & & & $\begin{array}{c}-0.020 \\
(-0.500)\end{array}$ & & & \\
\hline Competition restriction & & & & $\begin{array}{c}0.005 \\
(0.067)\end{array}$ & & \\
\hline State ownership & & & & & $\begin{array}{c}-0.046 \\
(-0.593)\end{array}$ & \\
\hline Banking supervision & & & & & & $\begin{array}{c}-0.028 \\
(-0.436)\end{array}$ \\
\hline Systematic banking crisis & $\begin{array}{c}0.228 \\
(2.679)^{*}\end{array}$ & $\begin{array}{c}0.185 \\
(1.861)^{* *}\end{array}$ & $\begin{array}{c}0.196 \\
(2.599)^{*}\end{array}$ & $\begin{array}{c}0.231 \\
(2.810) *\end{array}$ & $\begin{array}{c}0.234 \\
(2.254)^{*}\end{array}$ & $\begin{array}{c}0.264 \\
(3.331)^{*}\end{array}$ \\
\hline Consumption & $\begin{array}{c}-0.698 \\
(-1.586)\end{array}$ & $\begin{array}{c}-1.081 \\
(-1.726)^{* *}\end{array}$ & $\begin{array}{c}-0.627 \\
(-1.735)^{* *}\end{array}$ & $\begin{array}{c}-0.957 \\
(-1.448)\end{array}$ & $\begin{array}{c}-0.487 \\
(-1.680)^{* *}\end{array}$ & $\begin{array}{c}-0.546 \\
(-1.645)^{* *}\end{array}$ \\
\hline Agricultural growth & $\begin{array}{c}-0.002 \\
(-0.313)\end{array}$ & $\begin{array}{c}-0.001 \\
(-0.125)\end{array}$ & $\begin{array}{c}-0.003 \\
(-0.492)\end{array}$ & $\begin{array}{c}-0.001 \\
(-0.237)\end{array}$ & $\begin{array}{c}-0.001 \\
(-0.144)\end{array}$ & $\begin{array}{c}-0.004 \\
(-0.507)\end{array}$ \\
\hline Income, per capita & $\begin{array}{c}-0.042 \\
(-0.071)\end{array}$ & $\begin{array}{c}-0.273 \\
(-1.932)^{* *}\end{array}$ & $\begin{array}{c}-0.009 \\
(-0.026)\end{array}$ & $\begin{array}{c}-0.179 \\
(-1.797)^{* *}\end{array}$ & $\begin{array}{c}-0.086 \\
(-0.271)\end{array}$ & $\begin{array}{c}-0.039 \\
(-0.083)\end{array}$ \\
\hline Bank credit & $\begin{array}{c}-0.304 \\
(-2.710)^{*}\end{array}$ & $\begin{array}{c}-0.302 \\
(-3.297)^{*}\end{array}$ & $\begin{array}{c}-0.297 \\
(-2.248) *\end{array}$ & $\begin{array}{c}-0.301 \\
(-2.320)^{*}\end{array}$ & $\begin{array}{c}-0.298 \\
(-1.760) * *\end{array}$ & $\begin{array}{c}-0.349 \\
(-2.345)^{*}\end{array}$ \\
\hline Wage & $\begin{array}{c}0.204 \\
(1.384)\end{array}$ & $\begin{array}{c}0.169 \\
(1.504)\end{array}$ & $\begin{array}{c}0.190 \\
(1.569)\end{array}$ & $\begin{array}{c}0.201 \\
(1.753)^{* *}\end{array}$ & $\begin{array}{c}0.215 \\
(1.855)^{* *}\end{array}$ & $\begin{array}{c}0.214 \\
(1.722)^{* *}\end{array}$ \\
\hline Lag, dependent variable & $\begin{array}{c}0.811 \\
(8.570)^{*}\end{array}$ & $\begin{array}{c}0.773 \\
(11.232)^{*}\end{array}$ & $\begin{array}{c}0.824 \\
(11.152)^{*}\end{array}$ & $\begin{array}{c}0.801 \\
(7.526)^{*}\end{array}$ & $\begin{array}{c}0.808 \\
(11.503)^{*}\end{array}$ & $\begin{array}{c}0.830 \\
(7.557)^{*}\end{array}$ \\
\hline$R^{2}$ & 0.962 & 0.967 & 0.963 & 0.962 & 0.963 & 0.958 \\
\hline Adjusted $R^{2}$ & 0.951 & 0.957 & 0.952 & 0.951 & 0.953 & 0.947 \\
\hline S.E. of regression & 0.095 & 0.091 & 0.094 & 0.096 & 0.093 & 0.098 \\
\hline$F$-statistic & 105.276 & 113.700 & 106.831 & 108.455 & 107.246 & 106.361 \\
\hline $\operatorname{Prob}(F$-statistic $)$ & {$[0.000]$} & {$[0.000]$} & {$[0.000]$} & {$[0.000]$} & {$[0.000]$} & {$[0.000]$} \\
\hline Durbin $|h|$ test & 1.799 & 1.677 & 1.479 & 1.899 & 1.671 & 1.068 \\
\hline $\operatorname{Prob}(J$-statistic $)$ & 0.600 & 0.837 & 0.744 & 0.831 & 0.837 & 0.838 \\
\hline \multicolumn{7}{|l|}{ Normality Test } \\
\hline Jarque-Bera & 0.330 & 0.926 & 0.255 & 0.336 & 0.341 & 0.229 \\
\hline Prob(Jarque-Bera) & {$[0.847]$} & [0.629] & {$[0.880]$} & {$[0.845]$} & [0.843] & [0.891] \\
\hline
\end{tabular}

(Notes) (i) Values in parentheses are $t$-statistics.

(ii) $*$ and $* *$ indicate that the estimated values are statistically significant at the $5 \%, 10 \%$ level of significance, respectively. 
Table 4. Youth unemployment rate

(Estimated results)

\begin{tabular}{|c|c|c|c|c|c|c|}
\hline & (1) & (2) & (3) & (4) & (5) & (6) \\
\hline Constant & $\begin{array}{c}8.526 \\
(1.117)\end{array}$ & $\begin{array}{c}0.856 \\
(0.239)\end{array}$ & $\begin{array}{c}0.372 \\
(0.092)\end{array}$ & $\begin{array}{c}0.546 \\
(0.122)\end{array}$ & $\begin{array}{c}-0.444 \\
(-0.140)\end{array}$ & $\begin{array}{c}3.264 \\
(0.566)\end{array}$ \\
\hline Banking deregulation index & $\begin{array}{c}-0.287 \\
(-2.070)^{*}\end{array}$ & & & & & \\
\hline Interest rate control & & $\begin{array}{c}-0.090 \\
(-5.063) *\end{array}$ & & & & \\
\hline Credit control & & & $\begin{array}{c}-0.071 \\
(-5.873) *\end{array}$ & & & \\
\hline Competition restriction & & & & $\begin{array}{c}-0.180 \\
(-3.870) *\end{array}$ & & \\
\hline State ownership & & & & & $\begin{array}{c}-0.113 \\
(-3.278) *\end{array}$ & \\
\hline Banking supervision & & & & & & $\begin{array}{c}-0.065 \\
(-1.932)^{* *}\end{array}$ \\
\hline Systematic banking crisis & $\begin{array}{c}0.295 \\
(3.754)^{*}\end{array}$ & $\begin{array}{c}0.315 \\
(14.096)^{*}\end{array}$ & $\begin{array}{c}0.542 \\
(2.631)^{*}\end{array}$ & $\begin{array}{l}0.555 \\
(2.214)^{*}\end{array}$ & $\begin{array}{l}0.170 \\
(1.536)\end{array}$ & $\begin{array}{c}0.339 \\
(3.560)^{*}\end{array}$ \\
\hline Consumption & $\begin{array}{c}-0.883 \\
(-1.826)^{* *}\end{array}$ & $\begin{array}{c}-0.157 \\
(-1.822)^{* *}\end{array}$ & $\begin{array}{c}-0.309 \\
(-1.431)\end{array}$ & $\begin{array}{l}-0.176 \\
(-1.821)^{* *}\end{array}$ & $(-0.204$ & $\begin{array}{c}-0.169 \\
(-1.237)\end{array}$ \\
\hline Agricultural growth & $\begin{array}{c}-0.005 \\
(-1.225)\end{array}$ & $\begin{array}{c}0.001 \\
(0.305)\end{array}$ & $\begin{array}{c}(-0.006) \\
(-1.652)^{* *}\end{array}$ & $\begin{array}{l}-0.006 \\
(-2.770)^{*}\end{array}$ & $\begin{array}{c}-0.002 \\
(-0.412)\end{array}$ & $\begin{array}{c}-0.003 \\
(-0.645)\end{array}$ \\
\hline Income, per capita & $\begin{array}{c}-0.256 \\
(-0.496) \\
-\end{array}$ & $\begin{array}{c}-0.171 \\
(-0.569)\end{array}$ & $\begin{array}{c}-0.205 \\
(-1.667)^{* *}\end{array}$ & $\begin{array}{l}-0.339 \\
(-1.821)^{* *}\end{array}$ & \begin{tabular}{c}
0.012 \\
$(0.046)$ \\
\hdashline
\end{tabular} & $\begin{array}{l}(0.004) \\
(0.007)\end{array}$ \\
\hline Bank credit & $\begin{array}{l}-0.620 \\
(-2.527)^{*}\end{array}$ & $\begin{array}{l}-0.637 \\
(-2.997)^{*}\end{array}$ & $\begin{array}{c}-0.704 \\
(-2.441)^{*}\end{array}$ & $\begin{array}{l}-0.678 \\
(-1.988)^{* *}\end{array}$ & $\begin{array}{c}-0.252 \\
(-1.490)\end{array}$ & $\begin{array}{c}-0.585 \\
(-1.679)^{* *}\end{array}$ \\
\hline Wage & $\begin{array}{c}0.044 \\
(0.367)\end{array}$ & $\begin{array}{c}0.115 \\
(1.829)^{* *}\end{array}$ & $\begin{array}{l}0.118 \\
(3.125)^{*}\end{array}$ & $\begin{array}{c}0.146 \\
(7.150)^{*}\end{array}$ & $\begin{array}{c}0.247 \\
(3.055)^{*}\end{array}$ & $\begin{array}{c}0.165 \\
(1.365)\end{array}$ \\
\hline Lag, dependent variable & $\begin{array}{c}0.411 \\
(5.886)^{*}\end{array}$ & $\begin{array}{c}0.545 \\
(6.349)^{*}\end{array}$ & $\begin{array}{c}0.495 \\
(7.165)^{*}\end{array}$ & $\begin{array}{c}0.376 \\
(4.335)^{*}\end{array}$ & $\begin{array}{c}0.723 \\
(7.059)^{*}\end{array}$ & $\begin{array}{c}0.470 \\
(3.404) *\end{array}$ \\
\hline$R^{2}$ & 0.961 & 0.963 & 0.942 & 0.940 & 0.971 & 0.954 \\
\hline Adjusted $R^{2}$ & 0.950 & 0.953 & 0.926 & 0.924 & 0.963 & 0.941 \\
\hline S.E. of regression & 0.110 & 0.112 & 0.138 & 0.142 & 0.106 & 0.118 \\
\hline$F$-statistic & 81.264 & 96.081 & 73.721 & 101.235 & 128.232 & 84.706 \\
\hline $\operatorname{Prob}(F$-statistic $)$ & {$[0.000]$} & {$[0.000]$} & {$[0.000]$} & {$[0.000]$} & {$[0.000]$} & {$[0.000]$} \\
\hline Durbin $|h|$ test & 0.985 & 0.590 & 0.191 & 0.461 & 0.795 & 0.471 \\
\hline $\operatorname{Prob}(J$-statistic $)$ & 0.875 & 0.946 & 0.705 & 0.867 & 0.883 & 0.684 \\
\hline \multicolumn{7}{|l|}{ Normality Test } \\
\hline Jarque-Bera & 4.597 & 0.376 & 0.922 & 4.177 & 0.351 & 0.435 \\
\hline Prob(Jarque-Bera) & {$[0.100]$} & {$[0.828]$} & {$[0.630]$} & {$[0.123]$} & {$[0.838]$} & {$[0.804]$} \\
\hline
\end{tabular}

(Notes) (i) Values in parentheses are $t$-statistics.

(ii) $*$ and $* *$ indicate that the estimated values are statistically significant at the $5 \%, 10 \%$ level of significance, respectively. 
The control variables also have theoretically expected effects on unemployment rates. The estimated coefficients of systematic banking crisis are found to be positively and significantly related with both total and youth unemployment rates. This indicates that if a banking crisis occurs in the region, it will increase the unemployment rate. This result is robust with alternative equation specifications in the total unemployment rate but not in the youth unemployment rate. This result is consistent with the literature that banking crises positively affect the unemployment rate, especially youth unemployment rate (Bernal-Verdugo et al. 2012). Estimated coefficients of consumption appear with negative signs. This means that when consumption spending increases both total and youth unemployment decreases. The results are consistent with the literature that private and government consumption expenditures are associated with an increase in labor demand (Gruber 1997). The estimated coefficient on agricultural growth is negatively associated with both total and youth unemployment rates. However, it is not statistically significant in the total unemployment rate and is significant only in two specifications in youth unemployment rate. The magnitude of the coefficient is also trivial. This indicates that the agricultural sector has decreased youth unemployment in South Asia but only trivially. In fact, agriculture has become mechanized in these countries, which has not created employment. The agriculture sector is also unattractive due to risks, costs, inefficiency, and its labor intensive nature. Per capita income is negatively associated with the unemployment rates. This stipulates that an increase in income level helps to generate employment. This result corroborates with the theory that in the long run, the GDP growth rate decreases unemployment. However, this result is not robust with alternative equation specifications both in total and youth unemployment rates. The coefficient on bank credit is negative and statistically significant in both total and youth unemployment rates. This indicates that availability of credit to the private sector has helped in reducing unemployment in the region. Economically speaking, a one percent increase in bank credit (percentage of GDP) will decrease total unemployment by $0.304 \%$ and youth unemployment by $0.620 \%$. The wage rate coefficient appears with a positive sign, which reveals that unemployment increases with an increase in the wage rate. However, this variable is statistically significant only in a few equation specifications. ${ }^{7}$

These results show that banking deregulation increases the competitiveness and efficiency of the banking sector, which helps to provide easy access to credit, low

\footnotetext{
${ }^{7}$ To control for the unobserved year effect on total and youth unemployment rates, a dummy variable for the 9/11 event was included in the models as the selected countries, especially Pakistan, received a high amount of foreign remittances and grants from the US, as working front line state against terrorism. This variable was statistically insignificant; therefore, it is not included in the estimation.
} 
interest rate margins, and better allocation of resources including labor resources. The firms which depend on banks for credit can benefit from this and can invest and expand their production. These effects are the most important possible channel through which banking deregulation helps in increasing labor demand and contributes to the reduction of unemployment. Taken together, the results suggest that banking deregulations have considerably reduced youth unemployment in South Asian countries. These results corroborate the theoretical models of Acemoglu (2001), Wasmer and Weil (2004), and Battle (1997). These results also substantiate previous empirical research that liberalization of the financial sector favorably affects labor market performance.

\section{Conclusion}

The paper empirically examines the effect of banking deregulations on overall and youth unemployment rates in South Asian countries using panel data for the period 1991 to 2005. The estimated results show that banking deregulation decreases youth unemployment in the region. Specifically, reducing competition restrictions contributes the most in the reduction of unemployment. As far as control variables are concerned, high consumption expenditures and bank credits decrease unemployment in South Asian countries. Similarly, high per capita income and agriculture growth help reduce unemployment. Further, reducing the number of banking crises and the wage rate also decreases the unemployment rate.

The study has some important policy implications. South Asian countries need to further relax the entry of foreign banks as these banks would provide foreign capital, banking technology, and new financial instruments. It would increase competitiveness within the banking sector, which would increase the efficiency of the banking sector and more loans would be available to borrowers at low costs. South Asian countries should reduce credit controls and need to provide more credits to the private sector. For this purpose, banks may introduce new financial products that are relevant, impactful, and easy to use. Further, by increasing banking supervision these countries can improve the efficiency of the banking system which would be helpful in unemployment reduction. By reducing the number of bank crises and increasing government consumption expenditures, governments in South Asia can reduce the unemployment level. Finally, 
high income growth would reduce the unemployment rate. Some other banking regulation measures like securities market policy and capital account restrictions can also be added in the models. This is left for future research.

Received 14 January 2015, Revised 8 June 2015, Accepted 17 October 2015

\section{References}

Abiad, Abdul, Enrica Detragiache and Thierry Tressel. "A New Database of Financial Reforms." IMF Working Paper No. 226, 2008.

Acemoglu, Daron. "Credit Market Imperfections and Persistent Unemployment." European Economic Review 45 (2001): 665-679.

Baddeley, Michelle C. "Structural Shifts in UK Unemployment 1979-2005: The Twin Impacts of Financial Deregulation and Computerization." Bulletin of Economic Research 60 (2008): 123-157.

Battle, Ann M. "Welfare Effects of Liberalization Reforms with Distortions in Financial and Labor Markets." Journal of Development Economics 52 (1997): 279-294.

Beck, Thorsten, Ross Levine and Alexey Levkov. "Big Bad Banks? The Winners and Losers from Bank Deregulation in the United States." Journal of Finance 65 (2010): 1637-1667.

Bernal-Verdugo, Lorenzo E., Davide Furceri and Dominique M. Guillaume. "Labor Market Flexibility and Unemployment: New Empirical Evidence of Static and Dynamic Effects." Comparative Economic Studies 54 (2012): 251-273.

Blanchflower, David G. and Chris Shadforth. "Entrepreneurship in the UK." Foundations and Trends in Entrepreneurship 3 (2007): 257-364.

Boustanifar, Hamid. "Finance and Employment: Evidence from U.S. Banking Reforms." Journal of Banking and Finance 46 (2014): 343-354. 
Butkiewicz, James L. and William R. Latham. "Banking Deregulation as an Economic Development Policy Tool.” Southern Economic Journal 57 (1991): 961-974.

Caprio, Gerard and Maria S. Martinez-Peria. "Avoiding Disaster: Policies to Reduce the Risk of Banking Crises.” Working Paper No. 47, Egyptian Centre for Economic Studies, 2000 .

Claessens, Stijn and Luc Laeven. "What Drives Bank Competition? Some International Evidence.” Journal of Money, Credit, and Banking 36 (2004): 563-583.

Demyanyk, Yuliya. "U.S. Banking Deregulation and Self-employment: A Differential Impact on those in Need." Journal of Economics and Business 60 (2008): 165-178.

Dromel, Nicolas L., Elie Kolakez and Etienne Lehmann. "Credit Constraints and the Persistence of Unemployment." Labour Economics 17 (2010): 823-834.

Feldmann, Horst. "Credit Market Regulation and Labor Market Performance around the World." Kyklos 59 (2006): 497-525.

Feldmann, Horst. "Banking Deregulation around the World, 1970s to 2000s: the Impact on Unemployment." International Review of Economic and Finance 24 (2012): 26-42.

Garmaise, Mark J. "Production in Entrepreneurial Firms: The Effects of Financial Constraints on Labor and Capital." Review of Financial Studies 21 (2008): 543-577.

Gruber, Jonathan. "The Consumption Smoothing Benefits of Unemployment Insurance." American Economic Review 87 (1997): 192-205.

Hausman, Jerry A. "Specification Tests in Econometrics.” Econometrica 46 (1978): 1251-1271.

Krol, Robert and Shirley Svorny. "The Effect of the Bank Regulatory Environment on State Economic Activity." Regional Science and Urban Economics 26 (1996): 531-541.

Mehrez, Gil and Daniel Kaufmann. "Transparency, Liberalization and Banking Crisis." World Bank Working Paper No 2286, 2000.

Pagano, Marco and Giovanni Pica. "Finance and Employment." Economic Policy 27 (2012): 5-55.

Saeed, Abubakr. "Does Nature of Financial Institutions Matter to Firm Growth in Transition Economies?.” Eurasian Journal of Business and Economics 2 (2009): 73-90. 
Strahan, Philip E. “The Real Effects of US Banking Deregulation.” Federal Reserve Bank of St. Louis Review, 85 (2003): 111-128.

Wasmer, Etienne and Philippe Weil. "The Macroeconomics of Labor and Credit Market Imperfections.” American Economic Review 94 (2004): 944-963.

Wooldridge, Jeffrey M. Econometric Analysis of Cross Section and Panel Data. 2nd Edition: The MIT Press, 2002. 


\section{Appendix}

Table A. Correlation matrix

\begin{tabular}{|c|c|c|c|c|c|c|}
\hline & 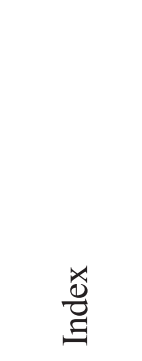 & 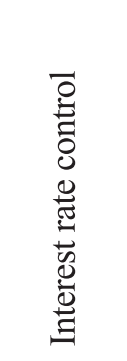 & 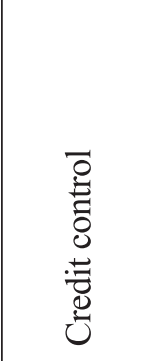 & 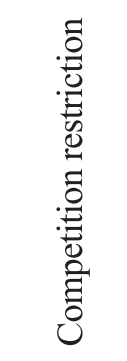 & 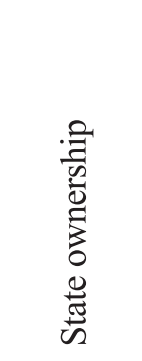 & 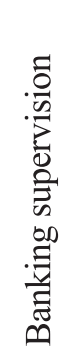 \\
\hline Index & 1 & & & & & \\
\hline Interest rate control & $\begin{array}{c}0.85 \\
(12.78) *\end{array}$ & 1 & & & & \\
\hline Credit control & $\begin{array}{c}0.74 \\
(8.60)^{*}\end{array}$ & $\begin{array}{c}0.49 \\
(4.28)^{*}\end{array}$ & 1 & & & \\
\hline Competition restriction & $\begin{array}{c}0.45 \\
(3.87)^{*}\end{array}$ & $\begin{array}{c}0.16 \\
(1.27)\end{array}$ & $\begin{array}{c}0.43 \\
(3.71)^{*}\end{array}$ & 1 & & \\
\hline State ownership & $\begin{array}{c}0.27 \\
(2.18)^{*}\end{array}$ & $\begin{array}{c}0.44 \\
(3.77)^{*}\end{array}$ & $\begin{array}{c}-0.23 \\
(-1.84)^{* *}\end{array}$ & $\begin{array}{c}-0.28 \\
(-2.26)^{*}\end{array}$ & 1 & \\
\hline Banking supervision & $\begin{array}{c}0.66 \\
(6.76)^{*}\end{array}$ & $\begin{array}{c}0.53 \\
(4.78)^{*}\end{array}$ & $\begin{array}{c}0.40 \\
(3.36)^{*}\end{array}$ & $\begin{array}{c}-0.11 \\
(-0.87)\end{array}$ & $\begin{array}{c}0.22 \\
(1.71)^{* *}\end{array}$ & 1 \\
\hline
\end{tabular}

(Notes) (i) Values in parentheses are $t$-values.

(ii) $*$ and $* *$ denote that the value is statistically significant at $5 \%, 10 \%$ level of significance, respectively. 